\title{
Pediculosis Capitis in Schoolchildren and the Marginality Index of the Metropolitan Area of Guadalajara, Mexico
}

\author{
María Ana Valle Barbosa \\ Centro Universitario de Ciencias de la Salud, \\ Departamento de Ciencias Sociales, Universidad de \\ Guadalajara, México \\ Armando Muñoz de la Torre \\ Centro Universitario de Ciencias de la Salud, \\ Departamento de Ciencias Sociales, Universidad de \\ Guadalajara, México \\ Raúl Robles-Bañuelos \\ Centro Universitario de Ciencias de la Salud, \\ Departamento de Ciencias Sociales, Universidad de \\ Guadalajara, México \\ María Guadalupe Vega López \\ Centro Universitario de Ciencias de la Salud, \\ Departamento de Ciencias Sociales, Universidad de \\ Guadalajara, México \\ María Elena Flores Villavicencio \\ Centro Universitario de Ciencias de la Salud, \\ Departamento de Ciencias Sociales, Universidad de \\ Guadalajara, México
}

a Corresponding author: mavalleb@yahoo.com.mx

How to cite: Valle Barbosa MA, Muñoz de la Torre A, Robles-Buñuelos R, Vega López MG, Flores Villavicencio ME. Pediculosis capitis in schoolchildren and the marginality index of the Metropolitan Area of Guadalajara, Mexico. Univ. Med. 2020; 61(3). https:/ /doi.org/10.11144/Javeriana.umed61-3.pedi

\begin{abstract}
Pediculosis capitis (PC) is a plague in schoolchildren around the world, there is a sub-record of cases of this infestation. It is important to expose the lack of studies on the problem, whose presence dates back ancestral times. Methodology: The marginality index in four schools is explored, together with the presence of PC in them. Public schools of the municipalities of Zapopan, Tonalá, Tlaquepaque, and Guadalajara, Mexico are studied. It is a descriptive, transversal and comparative research. Objective: To identify according to the marginality index if there are differences in the prevalence of PC in schoolchildren of four schools in the metropolitan area of Guadalajara, Jalisco, Mexico. Results: The sample consisted of 720 schoolchildren. A highest frequency of pediculosis in the female sex was determined, representing $82.35 \%$ of the infested students; a global prevalence of $4.72 \%$ and a cumulative prevalence of $51.94 \%$ was demonstrated, that is, more than half of the students have ever had lice. The presence of these parasites is more common in girls and in long hair. The schools that presented more PC cases are in the medium marginality index.
\end{abstract}

Keywords

lice infestations; students; marginality. 


\section{Introduction}

There are multiple causes for head itching, and one is the presence of pediculosis capitis (PC) (1). More than six million species of the phylum Arthropoda are known, and they are the most prevalent on the planet. They are invertebrate parasites with bilateral symmetry, multicellular, with segmented body. They have faceted eyes, with a $360^{\circ}$ vision. There are males and females, unless they are the most primitive (2).

The head louse is an arthropod whose name is derived from the Greek arthon (joint, union) and podos (feet, legs) (2). PC was discovered by Linnaeus in 1758, and belongs to the Phtiraptera order, because it lacks wings. They are characterized by having hooks that facilitate their adhesion to the host. They belong to the Pediculidae family, the Pediculus genus and the Pediculus humanus species, because they feed on blood and are specific to humans (3).

Head lice are small, obligate hematophagous ectoparasites. Their life cycle has three phases: the eggs, also known as nits, are oval in shape with a diameter of 300 to $500 \mu \mathrm{m}$, and an incubation period of 10 days; nymphs, which mature into their adult form within 19 to 25 days of oviposition, and the adults, male or female, dorsoventrally flattened; they reach a length of up to 1.5 to $3 \mathrm{~mm}$, are wingless, greyish white and, after feeding, they are dark red (4). They are blood-sucking parasites that live in the host's head. A 1-2 mm sheath of the scalp wraps around the nit and hair shaft, making the nit tightly cemented. Lice hatch in one week and become adults the next week. Spread depends on the mature adult lice (1).

PC infestation is present worldwide, with varying prevalence: from $35.2 \%$ in India to $56.8 \%$ in Argentina. The Clínica de Dermatología Pediátrica del Hospital General de Sonora reports that $\mathrm{PC}$ is the fourth most common (6.9\%), 54\% are children between one and four years of age, with no predominance of sex, most commonly between June and September. It also reports that a female can lay between 150 and 250 eggs. The cycle lasts two to three weeks and these parasites live for around 30 days.
Although this problem has been investigated, it has not been resolved. There is a need for the population to reconsider control practices and the use of antiparasitic products, which must be used safely. If a family member suffers from pediculosis, action must be taken quickly and safely to prevent the lice from spreading.

\section{Form of transmission}

PC, colloquially known as lice, is the infestation of the scalp and hair by human pediculosis. It affects millions of people worldwide, occurs in all socioeconomic groups and is common in overcrowded urban areas; girls aged 3-12 are the most affected. In the United States, African Americans have a lower infestation rate than other races, possibly due to the use of ointments and because they have curly hair. Like tinea capitis (ringworm), the prevalence is higher among school-aged children, and appears to be increasing (1).

Lice are parasites that adhere to people's hair by direct contact, in the form of eggs and live lice; they lodge in contaminated clothing or personal items (5), through combs, brushes, and direct contact with hair, headdresses, pillows, and clothing infested with nits and lice (1). One of the main risk factors is the increase in population density, which increases outbreaks at the beginning of the school year (3). Lice are usually transmitted by direct head-to-head contact or indirectly by exchange of fomites, such as combs, hats, clothing or personal items (4).

Today, PC affects people all over the world. Among the factors that contribute to its proliferation are the type of housing, the number of people living in it, the type of hair, and whether it is long and dark (6). It is also favored by lack of cleanliness, promiscuity and mobility of people, which causes a public health problem that does not distinguish sex, age, race or social status (7).

Some authors note that some current practices, such as taking selfies, facilitate transmission when heads come into contact with each other when taking photographs. This way, the lice pass from one hair to 
another, which facilitates their reproduction. The above according to the Fundación Mexicana de Dermatología, which noted that in Mexico there are between 6 and 12 million people with $\mathrm{PC}$, essentially in ages between 3 and 12 years, including children in daycare centers (8).

This infestation affects everyone, without social distinction, but most often developing countries. Eradication of the parasite is not easy, due to its biological characteristics; it requires time and dedication, and good results are not always obtained. Hence, it is recognized as a public health problem, due to its high prevalence in the school environment (9).

\section{Consequences of pediculosis capitis}

It is an international problem that predominates in children. Some health professionals tend to minimize this condition, as it is not a disease vector. This is why it is said that it does not constitute a significant risk (10).

Ectoparasitosis causes redness of the scalp, irritation and bumpiness (9). The condition affects the economy, the school environment and mental and social health. There is an intrinsic relationship between infestation and hygiene conditions (11). It is a highly contagious parasitic dermatosis which stands out for its frequency together with scabies; its high prevalence in the school environment has led to the use of various therapeutic means (12).

The infestation is asymptomatic in some people. In addition to itching and excoriations, secondary bacterial infections with allergic reactions may occur. Lice also cause psychological distress that can affect concentration and academic performance and sometimes lead to school drop-out (4). It is a difficult problem to deal with. It is accompanied by social rejection, as a result of the lack of information that leads to discrimination (3).

\section{Prevention and treatment of pediculosis capitis}

Due to its high prevalence among minors, $\mathrm{PC}$ is the second cause of school absenteeism in primary education in Oaxaca (8). The appearance of lice in students of schools in Mexico has been recognized and it has been shown that this condition does not distinguish between people. Such a situation generated concern among teachers and educational authorities. In Guadalajara, the presence of lice was mentioned in primary school students; therefore, some control strategies were carried out, such as personal hygiene or of school supplies, and avoiding sharing personal objects (13).

Recently there has been an increase in consultations for PC, mainly located in school groups. In 2018, when more than 25 million basic education students returned during the hot season, health authorities warned about the possibility of lice transmission and suggested implementing prevention measures to prevent their proliferation (14).

Some common treatments are oral antihistamines, antibiotic ointments containing DDT or benzyl benzoate, whose effectiveness is comparable to their risk of producing irritation (15). People have used other products empirically, such as alcohol, phenol (creoline), boric acid, petroleum, petroleum fats, gasoline, kerosene (bright light), burned car oil, brake fluid, dry wine, aloe vera, Bursera simaruba lin (gumbo-limbo leaves), Calocarpum sapota (red mamey seeds), Annona muricata (soursop leaves), Indigofera tinctoria (indigo roots), Luffa cylindrica (loofah fruit), Melia azederach lin (paradise plant leaves), Musa paradisiaca lin (banana leaves or stems), Nicotiana tabacum lin (leaf tobacco), Parthenium hysterophorus lin (bitter broom, ozone, amicodex, aspirin, leaves), Persea americana mill (avocado leaves or seeds), pork gall, chicken gall, human urine, piperacine, ozone, amicodex and aspirin (16).

Given this scenario, prevention and control strategies have been taken from natural treatments to chemical products. One of the 
main strategies is to constantly check the head for signs of pediculosis, the use of shampoo, vinegar and special fine combs for pediculosis (17).

\section{Social marginalization}

The National Population Council uses the concept of marginalization, whose primary function is to assist in "the definition of strategies and social policy." It is expressed as persistent inequality in the participation of citizens and social groups in the development process and the enjoyment of its benefits. This concept is observed in the localities and municipalities through the dimensions of education, housing and monetary income; while at the state level, population dispersion and exposure to marginalization in localities are added to them (18).

Marginalization is a concept situated within the theory of modernization, with which underdeveloped societies are measured. Measuring marginalization focuses on the lack of basic goods and services, captured in three dimensions: education, housing and income. Marginalization is a phenomenon that affects localities and not necessarily the people who live in them. Marginalized people do not participate, do not have political organizations to represent them, nor do they take part in the tasks and responsibilities to be undertaken for the solution of social problems, including their own (18).

The marginality index is a summary measure that allows to differentiate the various geographical units of the country according to the overall impact of the shortcomings suffered by the population (19).

As mentioned above, $\mathrm{PC}$ is considered to be a public health problem that has not been solved to date. Therefore, the purpose of this study is to identify whether schools with high marginality indexes are a source of risk for lice infestation.

\section{Material and methods}

This was a descriptive, cross-sectional, comparative study. The sample selection was multi-staged and stratified randomized. Fifteen students per grade were taken. In the last stage of the selection, it was considered relevant to ensure that the sample was balanced between men and women, so that the sample was not loaded to only one sex ( 7 men and 8 women, or 8 men and 7 women for each grade from first to sixth). 720 students participated, distributed between the morning and afternoon shift.

The sample for this study was taken from schoolchildren of both sexes in four schools in Guadalajara, Zapopan, Tlaquepaque and Tonalá, for a total of eight schools with different levels of marginalization; this in order to identify, according to the marginality index, if there are differences in the prevalence of $\mathrm{PC}$ in schoolchildren in the four selected schools. For this purpose, a questionnaire entitled Pediculosis Capitis in Schoolchildren was created by María Ana Valle Barbosa and Armando Muñoz de la Torre. The questionnaire has 43 items that measure the point and cumulative prevalence, and the association of factors related to PC. The instrument is organized into 5 sections: the first includes sociodemographic data; the second includes the personal characteristics of the respondent; the third, the important variables of housing; the fourth, the variables of the school, and the fifth, the variables characterizing the infestation. A Likert type scale was used to measure the 5 sections, which uses the following parameters: always, almost always, sometimes and never. A probabilistic test was applied to 720 schoolchildren. For the validation and reliability of the questionnaire, a Cronbach's alpha equal to 0.886 was used, based on the characterized elements. And the average of sampling adequacy of Kaiser-Meyer-Olkin (KMO) was determined.

For first and second graders, the form was applied orally, and for third through sixth graders it was self-applicable. The characteristics of the infestation were explained to the students beforehand, to avoid confusion with other scalp conditions. The team that applied the questionnaire confirmed that the respondents understood the specifications of pediculosis. Then, the forms were coded with Microsoft 
Excel, and the information was processed in EPI $\mathrm{INFO}^{\mathrm{TM}}$ for Microsoft Windows.

\section{Results}

There were 3621 students from the selected schools in the four municipalities under study, from which a sample of 720 students was formed, representing $19.88 \%$ of the total. It should be noted that the sample was chosen at random; therefore, some of those left out may have been infested. Despite this, with the selected group it was found that the presence of these parasites is a health problem in school children. Pediculosis was present in boys and girls of both shifts in all schools. Most of the identified cases belong to a highly marginalized population.

The study was carried out in schools with the following marginality indexes: school in the municipality of Tonalá, classified with a medium marginality index; Tlaquepaque, with a high index; Zapopan, with a medium index, and Guadalajara, with a low index (19). The sample consisted of 349 boys and 371 girls, corresponding to 180 students per school (Table $1)$.

Table 1.

Sample of students participating in the survey on pediculosis by gender and shift in the Guadalajara Metropolitan Area

\begin{tabular}{|l|l|r|r|r|}
\hline Municipality & \multicolumn{1}{|c|}{ Shift } & Males & Females & Total \\
\hline \multirow{2}{*}{ Guadalajara } & Morning & 42 & 48 & 90 \\
\cline { 2 - 5 } & Afternoon & 46 & 44 & 90 \\
\hline \multirow{2}{*}{ Tonalá } & Morning & 41 & 49 & 90 \\
\cline { 2 - 5 } & Afternoon & 44 & 46 & 90 \\
\hline \multirow{2}{*}{ Tlaquepaque } & Morning & 43 & 47 & 90 \\
\cline { 2 - 5 } & Afternoon & 39 & 51 & 90 \\
\hline \multirow{2}{*}{ Zapopan } & Morning & 49 & 41 & 90 \\
\cline { 2 - 5 } & Afternoon & 45 & 45 & 90 \\
\hline Total & & $\mathbf{3 4 9}$ & $\mathbf{3 7 1}$ & $\mathbf{7 2 0}$ \\
\hline
\end{tabular}

Data were collected using a questionnaire developed from the literature review, which obtained a Cronbach's alpha reliability index $=0.886$, with a $\mathrm{KMO}$ index $=0.849$ and exploratory factor analysis.

Thirty-four cases of pediculosis were identified. The morning shift in the municipality of Zapopan stood out for having a prevalence of $14.63 \%$ in girls, while in boys it was $2.04 \%$. This municipality has a medium marginality index.

Guadalajara, with a low marginality index, was the municipality with the fewest cases $(2.17 \%$, in men of the afternoon shift). It was evident that in the sample the infestation was more common in the female sex, with $7.55 \%$ for women and 1.72 $\%$ for men (Figure 1).

\section{Figure 1.}

Point prevalence (\%) of students who reported suffering from pediculosis capitis by municipality, shift and gender at the time of applying the survey in the Guadalajara Metropolitan Area

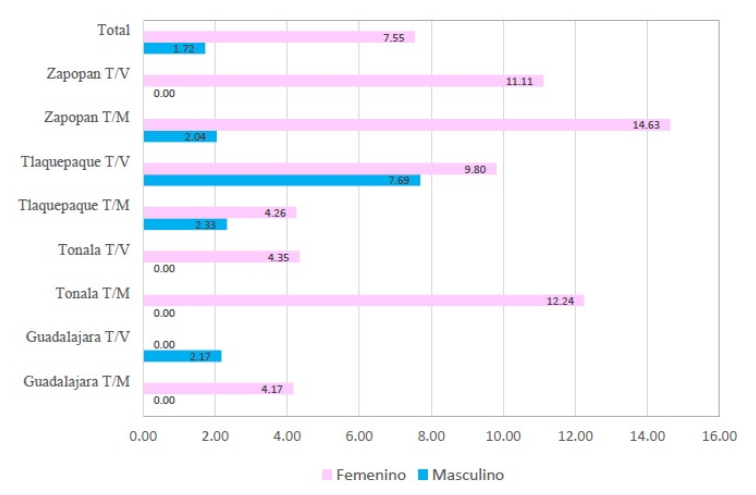

Based on the total results by municipality and shift, Tlaquepaque was identified as having a higher prevalence of cases of pediculosis, with $8.89 \%$ in the afternoon shift, followed by the morning shift, with $7.78 \%$. In addition, of the four municipalities studied, it has a high marginality index. The municipality with the fewest cases was Guadalajara, in its afternoon shift, with $1.11 \%$, additionally classified with a low marginality index; while Zapopan and Tonalá are defined with a medium marginality index (Figure 2). 
Figure 2.

Point prevalence (\%) of students who reported suffering from pediculosis capitis by municipality and shift at the time of applying the survey in the Guadalajara Metropolitan Area

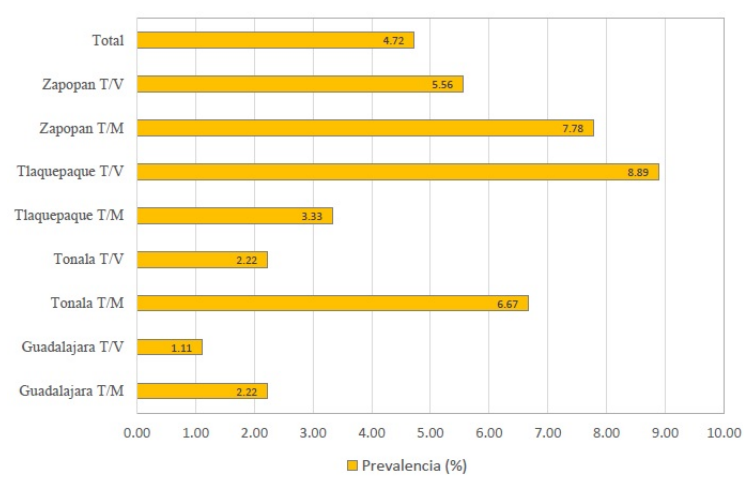

\section{Discussion}

PC is a worldwide condition. Some of the characteristics that contribute to its proliferation are the type of housing, overcrowding and the type of hair, which is predominantly long and dark in color (6).

Marginalization is not typical of third world countries; but it is more noticeable, due to the increase in poverty. Due to the economic crises in these countries, there is a prevalence of factors that make parasitism a public health problem (low socio-economic conditions, low cultural level, poor hygiene practices and overcrowding) (20).

These conditions are consistent with the results obtained in this research, in which the presence of these parasites is concentrated in the most marginalized schools. Despite the global prevalence of this infestation, it dominates in developing countries. It is not easy to eradicate it, due to the way the parasite reproduces. In addition, it requires time and dedication, and good results are not always obtained. It is a public health problem that mainly affects school groups all over the world (9).

The prevalence of $\mathrm{PC}$ in children was $32.63 \%$ $(235 / 720)$; it mainly affects $(7.22 \% ; 52 / 720)$ the female sex. Having long hair and the schooling level of the parents were significantly associated with this health problem (4). Girls with long hair are the most affected, as they have a higher prevalence of infestation in the most marginalized schools.

\section{Conclusions}

Pediculosis capitis continues to be a common problem in the school population, affecting schools with high social marginalization.

It is undeniable that marginality influences the presence of PC. The sample of schoolchildren in the municipality of Guadalajara has a low marginality index and a lower number of cases of PC.

Finally, PC is a health problem that does not lead to apparently serious diseases, but major scalp injury and even secondary infections could result, as parasites feed on the host's blood. Girls are the most vulnerable group. It is a condition that constantly leads to social stigma.

Conflicts of interest: the authors declare no conflict of interest.

\section{References}

1. Grimalt R. A practical guide to scalp disorders. J Investig Dermatol Symp Proc. 2007;12(2):10-4. https://doi.org/ 10.1038/sj.jidsymp.5650048

2. Tay ZJ. Microbiología y parasitología médica. México D. F.: Méndez; 1994. p. 256-8.

3. Quiroz-Herbert MA, ReyesHernández KL, Sánchez-Chávez NP, Reyes-Gómez U, Hernández-Lira S, Reyes-Hernández D, et al. Pediculosis. Bol Clin Hosp Infant Edo Son [internet]. 2015;32(1):22-5. Available at: https:/www.medigraphic.com/cgi-b in/new/resumen.cgi?IDARTICULO= 58104

4. Molina-Garza ZJ, Galaviz-Silva L. Pediculus capitis en niños de escuelas de la zona urbana de Nuevo León, 
México: análisis de factores asociados Biomédica. 2017;35(3). https://doi.org/ 10.7705/biomedica.v34i3.3311

5. Herranz JB, Abad IE. Pediculosis de la cabeza. Pediatr Aten Primaria [internet]. 2008 [cited 2019 sep];10(38):75-96. Available at: https://www.redalyc.org/pdf/3666/3 66638702008.pdf

6. Villanueva RJ, Arenas R. Pediculosis. Bogotá: Dermatología Ibero-Americana; 2000.

7. Valle BM, Robles BR, Vega LM, Muñoz de la T, Carrillo NG. La pediculosis en el sector educativo: medidas de control a través de la historia. Jalisco, MX: Editorial Universitaria de Guadalajara; 2014.

8. El Imparcial. Con piojos casi 12 millones de mexicanos. 28 de noviembre 2017 [cited 2019 Mar 20]. Available at: https://imparcialoaxaca.mx/salud/9 1272/con-piojos-mas-de-12-millones-d e-mexicano/

9. Llada Suárez R, Del Fresno Marqués L, Vidal Fernández S, Vázquez González N. Evidencia científica y recomendaciones sobre el tratamiento de la pediculosis. RqR Enfermería Comunitaria. 2018;6(3):25-41.

10. Oscar W, Tincopa W, Vera RJ. Pediculosis capitis: factores epidemiológicos, lesiones cutáneas y dermatosis coexistentes en niños de Trujillo, Perú. Arch Argent Dermatol [internet]. 2006; (56):219-26. Available at: http://www. archivosdermato.org.ar/Uploads/Arch. \%20Argent.\%20Dermatol.\%2056\%20 219-226,\%202006.pdf

11. Moncada LI, Ríos SM, Fernández JA, Rivas F, Sáenz ML. Prevalencia y factores asociados a la pediculosis en niños en un jardín infantil de Bogotá.
Biomédica. 2008;(28):245-51. https://d oi.org/10.7705/biomedica.v28i2.95

12. Bouvresse $\mathrm{S}$, Chosidow O. Ectoparasitosis: pediculosis y escabiosis. EMC Pediatría. 2011;46(3):1-7. https://doi.org/10.101 6/S1245-1789(11)71120-9

13. Azteca Noticias. Detectan brote de piojos en escuelas de Guadalajara, Jalisco [internet]. 11 de mayo de 2011. Available at: http://www.aztecanoticias.com.mx/ notas/estados/53806/detectan-brote-d epiojos-escuelas-de-guadalajara

14. Miranda P. Alertan por posibles contagios de piojos en escuelas. El Universal [internet]. 2018 Apr 9. Available at https://www.eluniversal.com.mx/na cion/sociedad/alertan-por-posibles-con tagios-de-piojos-en-escuelas

15. Díaz Martínez AG. Actualidades de la pediculosis. Rev Cubana Med Gen Integr [Internet]. 1997 Dic [cited 2019 Sep 4];13(6):610-8. Available at: http://scielo.sld.cu/scielo.php?script $=$ sci $\_$arttext $\&$ pid $=$ S0864-212519970 $00600015 \& \operatorname{lng}=$ es

16. Muñoz de la TA, Valle BM, Flores VM. Tratamientos más utilizados para el control de pediculosis capitis en escolares de la ciudad de Guadalajara, Jalisco, México. Rev Sal Jal. 2016:159-66.

17. Delgado CA, Kurdelas RK, Gamarra NK, Artola SB, Guerreiro $\mathrm{M}$ das N, Maure A, et al. Prácticas de prevención y tratamiento de la pediculosis capitis en Comodoro Rivadavia, Argentina. Lat Am J Pharm [internet]. 2010;29(1):132-6. Available at: http://sedici.unlp.edu.ar/ handle/10915/7882

18. Cortés F. Consideraciones sobre la marginación, la marginalidad, marginalidad económica 
y exclusión social. Pap Poblac [Internet]. 2006 [cited 2019 Jul 13];12(47):71-84. Available at: http://www.scielo.org.mx/scielo.ph p? script $=$ sci_arttext\&pid $=S 1405-742$ 52006000100004

19. Consejo Nacional de Población y Vivienda. La marginación en México [internet]. 2012 Juy 19. Available at: https://www.gob.mx/conapo/accion es-y-programas/la-marginacion-en-me xico.

20. Martínez E, Delgado M, Liu M. Prevalencia y factores condicionantes de la pediculosis capitis en escolares de Arequipa. Revista Peruana de Parasitología [internet]. 1995 [cited 2019 Jul 3];11(1):65-7. Available at: http://sisbib.unmsm.edu.pe/BVRevi stas/parasitologia/v11_n1/pdf/a17v11n 1.pdf 